\title{
A Curriculum of Kindness: (Re) Creating and Nurturing Heart and Mind through Teaching and Learning
}

\author{
Carmen Shields \\ Nipissing University \\ Vicki Reid-Patton \\ Top of the World Treatment Centre
}

\begin{abstract}
In this paper, we share stories of experience that focus on our belief that offering kindness as a key ingredient in teaching and learning provides a solid foundation for personal connection and sustained meaning-making. We highlight our past experience with teachers who provided us with caring and kindness and using a narrative process of recovering and reconstructing meaning, we move forward in time to describe how we now enact kindness in our own relationship and our work with students and clients in our present day practice as professor and counselor.
\end{abstract}

Keywords: narrative, curriculum, personal experience, teacher education, higher education.

Dr. Carmen Shields, Ed.D., is currently Associate Professor, Graduate Studies, in the Faculty of Education at Nipissing University, North Bay, Ontario. She teaches courses in Curriculum Leadership, Narrative Inquiry and Qualitative Research. Dr. Shield's approach to teaching and research is based in narrative inquiry and her research interests are in the areas of self-study, narratives of experience, women's perspectives, marginalization and belonging in institutional settings. Email: carmens@nipissingu.ca

Dr. Vicki Reid-Patton, Ph.D., is currently a clinical therapist at Top of the World Treatment Centre in Fort Steele, British Columbia. Her counseling and research interests are in the areas of addictions, narratives of experience, self-study and women and health.

Brock Education, Volume 18, No. 2, Spring 2009, 4-15. 


\section{Introduction}

The teacher is a mediator between the knower and the known, between the student and the subject to be learned. A teacher, not some theory, is the living link in the epistemological chain. The way a teacher plays the mediator role conveys both an epistemology and an ethic to the student, both an approach to knowing and an approach to living. (Palmer, 1993, p. 29)

We came to the writing of this paper as part of an ongoing process of inquiring into and naming seminal traits that underlie our present practice as professor and counselor. Since we first met more than ten years ago, our relationship has changed, and evolved from professor/graduate student to doctoral student and research participant to friend and colleague. Through these years, our personal and professional inquiries of thinking and practice have been the driving force that has connected us across time and distance. Although we did not engage in graduate study at the same time, we did have the shared experience of being at the same institution under the direction of professors whose teaching and research were based in narrative inquiry. We both completed our doctoral dissertations using narrative methodology.

As individuals who use narrative inquiry to frame experience for ourselves and for graduate students and clients, sharing stories of experience has become second nature. Like many of our own stories, those we hold within ourselves that others have shared as part of their learning processes are emotional - tales of loss and sorrow, as well as tales of wonder, and new insight. We have often spoken about what central traits are imperative for providing a milieu where such life experience can be shared. As we shared stories of teachers who hold a special place in our lives today, we realized that: while techniques such as slowing down, offering respectful silence, modeling caring and sharing in the rich dialogue of inquiry are critical elements of our teaching and therapeutic practice, the notion of kindness to others is the first step, the key factor for entering into an emergent learning space. How does one come to understand kindness as a grounding force in teaching and learning? What comprises the concept of kindness? An old thesaurus, The Merriam-Webster (1978) notes that kindness is "showing or having a gentle, considerate nature" and that being kindhearted is "showing or expressing affectionate interest in another" (p. 327). Freedman (1993) refers to kindness for others as "...a window of hope, one with the potential to illuminate many future paths (p. xxviii). Miller (2000) shares that in his university classroom he begins class by offering students a "lovingkindness meditation... [which] focuses on the development of compassion for all beings. It begins by sensing a basic warmth in our hearts, and then, gradually sharing this warmth and compassion with others" (p. 131).

For us, the concept of kindness as a basis for understanding curriculum has grown from our experiences with teacher/mentors who offered us compassion, respect and caring as we journeyed to voice our own learning. As we continued to work together over the years, we utilized the lessons learned from these teachers in our own continuing curriculum development. As narrative inquirers, sharing stories that speak to how we have come to construe kindness as a cornerstone for our practice as teacher and counselor, we were provided with the opportunity to engage in the two part narrative process described by Connelly \& Clandinin (1988). We remembered experience (recovery of meaning), and then reconstructing that experience to seek new meanings embedded in our work and in our present and imagined future life (reconstruction of meaning). 


\section{Discerning our Sense of Curriculum}

An important aspect of making public one's personal and professional curriculum theory is that a connection can be offered to others through sharing one's beliefs about teaching and learning in action or practice. Students or clients then have a way of understanding potentially abstract concepts, such as kindness, as part and parcel of the learning process. They can become beneficiaries of ideas, concepts and words that have the potential to connect them to their own curriculum theorizing and practice. For us, the kind attention and caring relationship of teacher/mentors who built their curricular practice with students in the milieu of their classrooms and lives, set the stage for our understanding of curriculum as it developed beyond the narrow confines of the institutional definitions that many teachers know and stand by. Connelly and Clandinin $(1988,2000)$, for example, write that curriculum is all of life's experience, but it was the gift of seeing this definition lived and modeled in Michael Connelly's classroom that made it a practical example to be experienced and passed on to others in our own subsequent teaching and learning. Schwab's (1962) notion of the commonplaces of curriculum where student, teacher, milieu and subject matter comprise curriculum, reminds us that these four aspects of curriculum intertwine in a learning space, and that often, it is the teacher and the atmosphere created that we remember across time rather than the subject matter. Understanding this insight from our own experience, we know that as teacher and counselor, we set the milieu that students or clients dwell in with us; that, in Palmer's (2000) words, as facilitators of the experience of others, we are the ones who shine a light, or cast a shadow over the learning of others by the very atmosphere we create. Knowing this is so, we have considered the writing of Pinar (1994), Palmer $(1993,2000)$ and others, who say that for a meaningful connection to be made in others' learning, we cannot stand apart from those we teach and counsel if we are to genuinely connect our theorizing with our practice and model that for others. It is up to us to set the stage for student and teacher or counselor to unravel new subject matter together in an atmosphere that is open to sharing from a personal perspective.

We use the work of Dewey (1938) as we consider the quality of the learning experience we try to build for ourselves and others in the classroom dialogue and interaction that forms the basis of our teaching and counseling practice. As Dewey writes, it is the quality of the experience upon which future learning depends. We feel that welcoming others into a space where kindness is modeled and lived is a critical ingredient for real engagement in the difficult process of personal meaning making, which is the heart learning. Further, we feel that the kindness felt helps infuse the dialogue and interaction with meaning, which connects students or clients to one another as well as to the subject matter, in a way that cannot be experienced otherwise.

Noddings (1984) writes that when we care for others we "have regard for what [they] think, feel and desire" (p. 9). For us, caring, like kindness, offers the window of hope to illuminate the future paths that Freedman (1993) described in his definition of kindness noted above. As professor and counselor, we want to be present and receptive for others, "to receive what is there as nearly as possible without evaluation or assessment" (p. 34). Carl Rogers (1961) termed this "unconditional positive regard" for the other. In such a setting, the one cared-for "grows stronger and feels not so much that he has been given something, as that something has been added to him" (Noddings, 1984, p. 20). In extending care and kindness, we try to open what Nouwen (1972) terms a free and fearless space for the other in which they feel welcomed and nurtured, and they can be authentic. 


\section{Learning From Stories of Past Experience}

Dewey (1938), describing the continuity of experience, wrote that: "every experience both takes up something from those which have gone before and modifies in some way the quality of those which come after" (p. 35). We put this notion to work in the stories that follow in the next section as we recover meaning from our past experience and reconstruct that meaning in the present for ourselves. Using this two step narrative inquiry process, we share stories of kindness that we have experienced with others in the past, and we reconstruct the meaning held there for us in the present. Since this narrative inquiry process is not static but ongoing across time, we can use it to help us understand that we know about the importance of kindness in our present practice, and also maintain an open door for new interpretations and additions of concepts on kindness.

\section{Stories of Kind Mentors}

Vicki's Story: Much of the teaching I have done over the past fifteen years has taken place in provincial and federal correctional settings, where I have worked as a counselor-educator. In the field of counseling, education takes the form of what is termed cognitive re-structuring, and my supervisor and mentor as I embarked on this journey was Dr. Charles Taylor, who was a pioneer in prison work in Canada and a faculty member of Acadia University. Charlie (as he was affectionately known to students and friends) received the Order of Canada in May of 2004, just weeks before his death at the age of 86. I have much to be grateful for as I look back over a friendship that developed over nearly 30 years. It was Charlie who was fond of saying that "only love heals" (Taylor, 1994, p. 11) and Charlie who taught me the truth of Samuel Johnson's words: "Kindness is in our power, even when fondness is not" (source unknown). In the classroom and in the prison, Charlie modeled a way of being in the world that involved more than a mastery of technique. He taught by example the value of authentic listening and the place of respect in facilitating change. His words, "We are more alike than different," continue to resonate in my counseling practice. It was through him that I first learned to look beyond the outward behavior and demeanor of the client and his/her sometimes lengthy and disturbing criminal record to see the person within, and through Charlie that I came to understand that our own most painful personal experiences can become the fertile ground from which compassion and kindness spring.

Considering this story now, I think of Palmer's (1998) notion of working with integrity, which I conceive of as a companion attribute to care and kindness. Palmer writes that until we have "sounded our own depths" we cannot sound the depths of our students' lives (p. 31). I know from my experience with Charlie that if I do not know "the self who teaches [or counsels]" in any meaningful way, if I have not gotten my own bearings, I cannot work with integrity with my clients or students. It is in recalling "my own long and continuing journey toward selfhood... and the slow pace of my own self-emergence" that my clients and students are spared from my imposing "excessive and unreal expectations" upon them (Palmer, 1998, p. 24). I think also of Van Manen (1991) who writes that students (and clients) do not come to us as "empty vessels [waiting] to be filled" ( $p .7)$ but come to us from somewhere. They come to us with a history and it is this history which shapes the learning which does or does not take place. I believe that the 
extension of kindness effectively challenges negative predispositions and perceptions of self and the world, opening up new possibilities.

Carmen's Story: In 1997, in a chapter of my doctoral thesis, I wrote about several teachers who had mentored me. Although I was writing about inclusion in special education then, through reflection on the actions of these teachers, I came to understand that the concept of inclusion was universal in nature-that it was something we could each do for one another in our lives. Over the years since then, I have considered the gifts inherent in being included by these individuals and have worked to name the gifts I received so that I could use them in my own teaching life. Among words and terms like 'openness,' 'hospitality,' and 'caring,' the word 'kindness' has taken a primary place. It seems to me that without kindness, the effort to include falls short. As the two stories told here demonstrate, approaching another with kindness allows for the other attributes, noted above, to unfold.

Story Clip 1: The year before my eldest daughter was born, I was a mature student on a small, conservative, university campus. I was living with my companion on a small income, studying under the supervision of a professor who was a well known scholar and administrator. I remember I sat spellbound as he lectured, experiencing the depths of real and connected learning for the first time in my life. Our relationship grew from our conversations about my need for part time work along with my studies, and continued in his care for me when my mother was diagnosed with breast cancer and I had to be absent for a number of weeks to be with her. He saw to it that I became a teaching assistant and one day, knowing that money was tight, he asked me to stop by his house on my way home. Dreading the extra work that I assumed I was picking up to fulfill my duties, I was surprised when he met me at the door with two large plastic bags in his hands. Reminding me that it was important for me to be eating well, he handed me the bags which contained steak and hamburger and vegetables frozen from his garden. In the years that followed, such kindnesses continued in various forms as I completed my degree and went on to become a teacher.

Story Clip 2: During my Masters in Education years, my supervising professor was a wonderful teacher of special education. He was a believer in learning by doing, and I would find myself traveling with him to conduct assessments in the schools or participate in seminars at other universities. Along the way he would regale me with stories from his own life and teaching days, treating me as a friend and colleague. Over time, this teacher became a family friend, even insisting that we take the key to his cottage for a summer while he was away in Europe, scoffing at the idea of any payment. He opened the world of special education to me as a teacher, and taught me by his own example that including another was a kindness we could all offer one another. I have never forgotten.

Vanier (1998) writes of role models: "A model is someone who demonstrates new ways of living..., someone who remains loving and humble..., someone who does not judge or condemn. Through their lives, these people show us the bigger picture" ( $p .131)$. That is what I feel these mentors did for me and now, using their example, it is what I try to offer others in my own classroom. I know from experience that offering students kindness is part of the invitation to learn from the depths of their being - a place that can connect heart and mind in an atmosphere of care and compassion. 


\section{Stories of Kindness for One Another: Different Roles Across Time}

\section{A University Classroom}

Vicki's Story: Our relationship began as a professor-student one and over time, has evolved into a reciprocal and collaborative one where mutual learning and teaching form the basis of our personal and professional friendship. It all began with the fostering of an attitude of kindness extended in the classroom where as professor, Carmen created a milieu in which space was made for multiple voices to join in class discussion and inquiry, and critical reflection was welcomed and encouraged.

When Carmen and I met in 1997, she was teaching a graduate level course in Qualitative Research Methods at the university where I was enrolled. I was completing the course work for my Master's degree in Education, and trying to decide whether or not to write a thesis. As I weighed my options I knew that, if I chose to write one, it would have to be on a topic for which I could sustain a high degree of energy. I was interested in researching issues associated with childhood abuse and particularly the re-experiencing of trauma in nightmare form. Working all day with traumatized clients as a supervised student counselor in the prison system, left little emotional energy for also writing about the same issues outside office hours. I needed to find another topic. From experience I also knew that in my department, it was scientific inquiries that held merit. A thesis needed to be comprised of data that could be quantified, measured, verified and replicated. Recovery from trauma was not a topic that lent itself well to quantification.

I had almost decided to forego the thesis option when I found myself in Carmen's office one day after class. Sharing her doctoral thesis with me, and binders full of readings on narrative research from her recent doctoral courses at the Ontario Institute for Studies in Education, University of Toronto, she challenged my perceptions regarding what constituted valid research. In this first encounter, Carmen opened what I have come to regard as one of the first hospitable spaces I had ever known academically. In giving me permission to explore my own life experience narratively, I experienced firsthand what it meant to be validated as a person, and I also acquired a new appreciation for the deeper and more difficult stories which my clients had to tell and the courage which brought them to my door.

Carmen's Story: Part of graduate student supervision for me is building a strong, personal relationship with students so that I understand their research as it connects to their lives. In 1998, in the midst of Vicki's masters thesis writing, I resigned from my university position and moved to another province. I arranged to complete my thesis supervision anyway, as relationships had been built with my students and narrative research was not common in that faculty at that time. Vicki and I found ourselves fifteen hundred kilometers apart. We developed the habit of talking on the phone in the early mornings before our days began to talk about chapter edits and ideas that Vicki was thinking about as she continued her research. Much like my experience with my former mentor, Vicki visited me in my new home. She and another graduate student accompanied me to an annual American research conference where I was giving a paper and where many narrative papers were presented. For me, the physical distance between us resulted in my understanding that the milieu I created was of particular importance as I wanted Vicki to feel that she was well supported; that she was never abandoned in spite of 
my not being on site as other supervisors were. Our friendship grew from this experience, and as I sat at her defense where she excelled and was nominated for a governor-general's prize for her work, I felt that her trust in me as a supervisor and person was a gift that had grown from respect and care earned between us over the distance. Our attitude of kindness toward one another was secured in that work, and has continued on to the present day.

\section{A Thesis Proposal Takes Shape}

Vicki's Story: With Carmen's encouragement, I began to explore the possibility of pursuing doctoral studies at OISE/UT after graduation, and enrolled there in the fall of 2000. During the course of my first semester, I was called upon to review a textbook chapter on duography and to present this to a class in Teacher Development. In their book, The Postmodern Educator, the authors, Patrick Diamond and Carole Mullen (1999), defined duography as "a retrospective written account that two people provide of a shared experience" (p. 317), a "turn-taking in writing" in which each responds to the other's stories. I thought that rather than simply talking, I might ask Carmen to join me, sharing our experience together as thesis supervisor and student. We did not write or follow a script as such for this presentation, but allowed the words to flow in much the same way as a duography would - building upon the other's stories, using the metaphor the authors provided of climbing the mountains of higher learning, "roped together" (Diamond and Mullen, p. 315).

Reflecting back on the seamless and effortless way in which this came about, I believe now that the spark of an idea presented itself to me then. What if my doctoral thesis explored the mentoring/co-mentoring relationship and the evolution of identities from our two perspectives? What if Carmen became my thesis participant? The recurring image of the old farmhouse where I grew up had been a powerful one in my Master's thesis, and one which had resonated for Carmen as she reflected on her own childhood home. What if we both wrote about the houses we had lived in as Jungian representations of the psyche or the self? Over coffee at the kitchen table the metaphor evolved, and the thesis began to take shape. We would begin to write letters back and forth, and these would become the field texts of my research.

Carmen's Story: During Vicki's thesis process while we were writing letters back and forth as a method of inquiring into our past experience, we took an opportunity to co-write a paper about our use of the metaphor of the house as a tool for reinterpreting our life experience. As we wrote that paper together, still with the distance of two provinces between us, I began to see that a shift was occurring in our relationship. I saw that Vicki was teaching me, using her expertise as counselor, to enlarge my view of my own life. I saw that we really had become co-teachers in the process of being co-researchers. 'Co-researchers' is a term Vicki used in her thesis to describe our work together. I can't say that I understood what that meant at the beginning, but now I know from my own experience that it refers to the careful intermingling of thoughts and perspectives spoken and heard, a shared respect built on knowledge constructed in the kindness given and taken over the years as we have gotten to know each other.

Thinking about these events and situations now, it seems that we were living out the notion of continuity of experience that Dewey (1938) describes as we adopted new roles in our relationship, remaining grounded in the ethic of kindness that we had constructed together in prior years. Dewey reminds us that "the principle of regard for ...decency and kindliness of human relations comes back in the end to the conviction that these things are tributary to a 
higher quality of experience..." (p. 34), which is what I feel, occurred for us during those years together.

\section{Living Examples of Our Curriculum Legacy in Teacher/Counselor Practice}

As well as looking back at the formative roots and personal application of our beliefs about curriculum, we want to extend the circle of learning described in this paper by sharing how our version of curriculum plays out as we teach and counsel others. As Friere (1998) describes, theorizing comes to life in action or practice: our beliefs about learning must be solid as we make them visible to others in our daily interactions. Too often, we see that the pretenses of power connected with a teaching and counseling life are used to remove voice from clients and students. In our practice we actively work against that stance, believing that the building of relationships among and between individuals provides a better model for those who have come together to learn. Foundational to this belief about practice is the notion that each student or client we teach is on their own learning journey, as are we, and that it is often the kind invitation to join forces to further that end that supports learning for everyone.

In our work, modeling aspects of kindness such as respect and consideration for individuals lays the groundwork for caring to be perceived by students and colleagues as the critically important element for learning. Central to our practice is the building of a milieu that assures a sense of trust, so that the sharing of experience, in the form of a rich and personal dialogical exchange, can be taken seriously. To engage in this process, we present new curriculum theorizing as a platform to share personal perspectives and build on understandings so that the group can support learning for one another. We seat people so that we can see one another, which helps sustain the careful and respectful listening that is so critical for a real exchange of ideas. We begin by sharing our own stories of experience, believing that we should take the first step in a process we are asking others to participate in. We monitor the pace of the class so that time is given for digesting ideas that may be new, or may be being experienced with new insights.

\section{A Kind Approach When Counseling Another}

Vicki's Story: A few years ago, I was working with a young woman struggling with a serious drug addiction. She had not been using for some time, when during one of our sessions, she asked to be excused to go to the washroom. I found out later that in that interval, she had gone into a colleague's office, had found a purse left unattended, and had removed the woman's wallet and pocketed it. The remainder of our session had gone without incident and my client had left the building before news of what she had done filtered down through the staff. It was left to me to handle it, when I met with the client again.

As our next counseling session began, she was unaware that this incident had been brought to my attention in the interim. She came in smiling in her usual jovial way. I sat across from her smiling too in silence for a moment, and then broached the subject by asking gently, "Do you want to tell me about the wallet?" She looked shocked for a moment, but then made no effort to deny her actions. Her eyes filled with tears as did mine, as she spoke, and she apologized for what she had done. She went on to disclose a lifelong history of taking things, a compulsion which she had never confessed or discussed with anyone else. The shame she felt was obvious, and she felt that she no longer deserved the counseling which had been offered her. 
She was "hopeless" and "good for nothing". After some time, I hugged her, and told her that was not how I saw her. I was not giving up on her. "We have work to do. That's all."

I suggested we bring in the woman whose wallet she had taken, so she could apologize to her as well. My colleague's approach with the client was also gentle, and the epitome of kindness. She listened respectfully to the confession and apology, then went on to explain how embarrassing it had been for her to find herself at the supermarket check-out without funds to cover her purchases, the feeling of panic and betrayal, the effort of canceling and now replacing credit cards and identification papers. Throughout this quiet conversation, my client wept softly, apologizing again and again. At the end of this time, the two women hugged, and arrangements were made whereby my colleague would be reimbursed the cash which had been taken, as well as have her wallet and its contents, which my client still possessed, returned.

This exercise of confrontation and mediation was the beginning of some of the most productive work I have ever done with a client, and led into work on deeper issues and eventually prolonged recovery for the client. Although we have since lost touch, I remember there was a distinct difference in the way she carried herself. She was eventually empowered to remove herself from an abusive spousal relationship believing she deserved better, and she landed a decent job that would support her and her daughter.

\section{Kindness in a Graduate Classroom: Compassionate Listening From the Heart}

Carmen's Story: There is always an invitation to share written assignments in my classes. In a recent term, about half way through our course, I asked students to write about one item they have kept and what the significant lessons might be attached to that object in their lives today. One young teacher who had been relatively quiet in the course offered to share her story. She read to us about losing an eye to cancer and about the gifts she felt were held for her in her glass eye. She described the professional work of painting a glass eye so that it appears to be real and a perfect match for an individual's real eye. She had kept her first glass eye from earlier years and passed it around the circle so that we could see the quality of the workmanship and feel her gratitude. She read in a strong and powerful voice in a silent room where we sat listening and feeling the depths of the story being shared. She spoke of her increased understanding of her own students' lives because of her experience, of the importance of care received from family and strangers alike, and of her own renewed capacity to learn. Through her sharing, she allowed us to see her in a new and personal light, and as I gently responded to her story, students around the table reacted with kindness and compassion, speaking from the depths of their own personal experiences as well.

Reflecting on these stories now, we are reminded of the gift of openness to new perspectives that we see given and received as students and clients make new meaning for themselves through sharing in the lived experience of one another. We also are beneficiaries of gifts in the form of new learning and friendships with others intent on learning through the process of shared experience.

\section{Conclusions}

As noted in the stories told in this paper, kindness has the power to restore dignity and extend grace even when it seems undeserved. Kindness can bring with it healing and restoration. It seems to call forth the best in the other. Kindness is a response to the perceived value of the 
other, an acknowledgement of the sanctity of life and the dignity of all humanity. In embracing kindness as the cornerstone for teaching and learning, we see that we can create situations that offer others the respect and consideration that is so essential for learning to occur.

We believe that the quality of learning experiences is enhanced when we place student and teacher at the forefront of our teaching and counseling practice. Subject matter is made more meaningful because it is embodied and shared within the context of the events, situations and experiences of those who have come together to learn. Our shared stories can bind our hearts and minds together so that we are able to make meaning that becomes part of our being. Like Ferrucci (2006), we believe that "kindness and the goodwill of many is a resource, an energy...it would be immensely useful to pay more attention to it, find ways of evoking it..." (p. 272). That is what we try to do in our teaching and counseling practice. Like Palmer (1993), we are mindful that we teach "a way of being in the world" (p. 30) to others as a process in our curricular practice. We want kindness to be a gift given and received in that process. 


\section{References}

Clandinin, D. J., \& Connelly, F. M. (2000). Narrative inquiry: Experience and story in qualitative research. San Francisco: Jossey-Bass.

Connelly, F. M., \& Clandinin, D. J. (1988). Teachers as curriculum planners. New York: Teacher's College Press.

Dewey, J. (1938). Experience and education. New York: Collier Books.

Diamond, C. T. P., \& Mullen, C. (1999). The post-modern educator: Arts-based inquiries and teacher development. New York: Peter Lang.

Ferrucci, P. (2006). The power of kindness: The unexpected benefits of leading a compassionate life. New York: Penguin Group.

Freedman, M. (1993). The kindness of strangers: Adult mentors, urban youth, and the new voluntarism. Cambridge: Cambridge University Press.

Friere, P. (1998). Pedagogy of freedom: ethics, democracy, and civic courage. Oxford: Rowman \& Littlefield

Miller, J. (2000). Education and the soul: Toward a spiritual curriculum. Albany: State University of New York Press.

Noddings, N. (1984). Caring: A feminine approach to ethics and moral education. Berkley: University of California Press.

Nouwen, H. (1972). The wounded healer. New York: Image/ Doubleday.

Palmer, P. (1993). To know as we are known: Education as a spiritual journey. New York: HarperCollins.

Palmer, P. (1998). The courage to teach: Exploring the inner landscape of a teacher's life. San Francisco: Jossey-Bass.

Palmer, P. (2000). Let your life speak. San Francisco: Jossey-Bass.

Pinar, W.F. (1994). Autobiography, politics \& sexuality: Essays in curriculum theory, 19721992. New York: Peter Lang.

Rogers, C.L. (1961). On becoming a person. Boston: Houghton Mifflin.

Schwab, J. (1962). The teaching of science as enquiry. In J.J. Schwab \& P. Brandwein (Eds.). The teaching of science. Cambridge, MA: Harvard University Press. 
Taylor, C. (1994). Counseling prisoners addicted to crime. Hantsport, N.S.: Lancelot Press. The Merriam-Webster Thesaurus (1978). New York: Pocket Books.

Vanier, J. (1998). Becoming human. Don Mills, Ont.: House of Anansi Press.

Van Manen, M. (1991). The tact of teaching: The meaning of pedagogical thoughtfulness. London, Ont.: Althouse Press. 